\title{
Job Satisfaction: Through Career Development and Work Environment
}

\author{
Achmad Mohyi \\ \{mohyimadura@gmail.com\} \\ University of Muhammadiyah Malang, Indonesia
}

\begin{abstract}
This study aims to describe career development, work environment and employee job satisfaction and determine the effect of career development and work environment partially or simultaneously on employee job satisfaction. The objects in this study were employees of Sengkaling Recreational Park with the sample studied amounted to 74 people or $50 \%$ of the population. Data analysis uses scale range and multiple linear regression. Hypothesis testing using $\mathrm{t}$ test and $\mathrm{F}$ test. The results showed that employee job satisfaction was sufficient, career development was sufficient and the work environment was also classified as sufficient. The results of the regression analysis showed that career development and work environment had a significant and partially significant effect on employee job satisfaction. The results of this study suggested that companies should pay more attention to employee career development by more actively socializing providing understanding and direction about the career needs of employees in each division.
\end{abstract}

Keywords: job satisfaction, career development, and work environment.

\section{Introduction}

Job satisfaction is an important thing that is felt by everyone at work. The level of job satisfaction will affect someone in completing their work, if the level of job satisfaction of employees is high then the company can achieve its objectives well. Job satisfaction can basically be felt by each individual and each individual has a different level of satisfaction. This can be seen from the attitude and how each individual does his job well. When able to carry out their work well, employees want to be given the opportunity to advance by the company. When the opportunity is given by the company, employees will feel satisfied and valued by the company.

Career development is one way that can be done to provide advanced opportunities for employees. Factors that influence job satisfaction are autonomy and independence, benefits, career advancement opportunities, career development opportunities, compensation or salary, communication, contribution, work environment, job security, etc [1]. From the above understanding, career development and work environment is one of the factors that can affect employee satisfaction.

Career development is one of the factors that can affect job satisfaction. Career development is the process of increasing individual work skills achieved in order to achieve the desired career [2]. The aim of all career development programs is to match employee 
needs and goals with career opportunities available in the company today and in the future. Career development is also determined through individual career development where each employee must accept responsibility for career development or experienced career advancement [2]. Furthermore, career development must also be supported by the HR Department which states that an employee's career development does not only depend on the efforts of the employee, but also depends on the role and guidance of the manager and the HR department [2]. Based on interviews with several employees, HR Department support is still lacking. Sometimes it is only through informal communication and does not cover all departments in the company. Lack of guidance by the HR Department indicates a lack of role or support from the HR Department.

Career development had a direct effect on teacher's OCB, perception of organizational justice had a direct effect on teacher's OCB, job satisfaction had a direct effect on teacher's $\mathrm{OCB}$, career development had a direct effect on teacher's job satisfaction, perception of organizational justice had a direct effect on teacher's job satisfaction [3]. There is positive relationship between career development and employee job satisfaction in banking sector [4]. Employees are satisfied with career development activities that are offered at their organizations. Corporate world has become more competitive hence employees have become more conscious to career development.

In addition to career development one of the factors that can affect job satisfaction is the work environment. Work environment is everything that exists around the workers or employees that can affect employee job satisfaction in carrying out his work so that maximum work results will be obtained, where in the work environment there are work facilities that support employees in completing tasks burden the employee [5]. Basically, every company will try to build a conducive work environment for its employees, so that every employee who works can do his work happily. That way employees are able to carry out their work properly, as well as obtain optimal work results and ultimately increase employee job satisfaction itself. The efficient human resource management and maintain good work environment or culture effects not only the performance of employee and organization but also affects the growth and development of entire economy [6].

The previous research that discusses career development and work environment on job satisfaction have some different findings. Career development and work environment has a significant effect on job satisfaction [7], while other researchers found that career development has a negative effect on job satisfaction [8], and the work environment has a negative effect on job satisfaction [9].

Related to career development, work environment and satisfaction issues, the author conducts research and will elaborate various things regarding the description of the implementation of career development, work environment and job satisfaction of Unmuh Malang recreation park company employees, analyzing the effect of career development and work environment on employee job satisfaction.

\section{Research Method}

This study used a survey method, with a sample of 74 people. The data analysis technique uses a range of scales and multiple linear regression. 


\section{Result and Discussion}

The results of the scale range analysis describe job satisfaction, career development and work environment as follows: 1) It was concluded that the job satisfaction of Sengkaling Recreational Park employees was quite satisfied to feel the results of the work performed which included work content, supervision, coworkers and working conditions with an average score on a scale range of 207;2) The results of the analysis of the overall scale range on career development variables is enough with a total score of 888 and an average score of 222 . The score reflects career development programmed sufficiently in order to achieve the desired career through individual career development and the human resources department and the role of leader and feedback on career development; 3) The results of the work environment analysis conclude that the high intensity of the sound that can disturb the peace of employees, shows the acquisition of a scale range score of 287 which is included in both categories. That is, the company is able to conducive the high intensity of sound that can interfere with the work of employees properly.

The results of multiple linear regression analysis explain the effect of career development variables and work environment on job satisfaction variables as described in Table 1.

Table 1. Results of Multiple Linear Regression Analysis

\begin{tabular}{llll}
\hline Variable & $\begin{array}{l}\text { Regression } \\
\text { Coefficient }\end{array}$ & t test & Sig. T \\
\hline Constanta & -1.541 & & \\
Carrier Development (X1) & 0.697 & 6.114 & 0.000 \\
Work Inveronment (X2) & 0.431 & 5.803 & 0.000 \\
\hline
\end{tabular}

Based on Table 1, the regression equation can be obtained as follows:

$$
\mathrm{Y}=-1.541+0.697 \mathrm{X} 1+0.431 \mathrm{X} 2
$$

From this equation it can be explained that:

a. $\mathrm{Y}$ is a dependent variable whose value will be predicted by independent variables. The dependent variable in this study is job satisfaction whose value will be predicted by the career development variable (X1) and work environment (X2) on the employees of Taman Sengkaling Malang.

b. a is a constant value or estimated value of job satisfaction of Malang Sengkaling Recreational Park employees that is equal to $-1,541$ which means that if career development and work environment is absent then the value $\mathrm{Y}=-1.541$.

c. b1 is the regression coefficient for career development variables (X1) of 0.697 which means that the influence of career development on job satisfaction is positive. If the career development provided by the company has increased, then employee job satisfaction will increase with the assumption that other variables are missing or zero. Thus, if the career development given to the employees of Taman Sengkaling Malang is getting better, employee satisfaction will be higher.

d. $\quad$ b2 is the regression coefficient value for the work environment variable (X2) of 0.431 which means that the influence of the work environment on job satisfaction is positive. 
If the working environment in the company gets better, employee job satisfaction will increase assuming other variables are missing or zero. Thus, if the working environment of Malang Sengkaling Recreational Park employees is getting better, then employee job satisfaction will increase.

\section{Employee Satisfaction at Sengkaling Recreational Park}

Based on the results of the distribution of questionnaires and data analysis, it can be seen that job satisfaction in the Company has a scale range of 207 and is included in the sufficient category. That is, employees have enough satisfaction with the contents of the job, supervision, coworkers and working conditions. Employees have enough satisfaction with their work. This means that the employee is quite capable of carrying out the work received in accordance with the area of expertise of each individual. However, there are still some employees who are placed in positions that are not in their area of expertise.

For supervision to have sufficient categories, employees have sufficient satisfaction with supervision. These results are consistent with the statement in the background, supervision in the company tends to less direct the duties of the employees. In addition, it is not uncommon for misunderstandings between superiors and supervision to result in the disruption of employees doing their work activities. Peer relations have enough categories, this potential is caused by employees in the company who are entrenched in establishing social relationships so as to cause social jealousy and lead to poor employee relations.

Besides the conditions of work included in the category enough. facilities in the company are quite complete such as places to eat, prayer rooms, toilets, table tennis and lava parking. However, the condition of the facilities is poorly maintained, such as dusty prayer rooms and toilets, there are still mosquito larvae, making them less comfortable for employees to use.

\section{Career Development of Employees at Sengkaling Recreational Park}

Based on the data it can be seen that the career development of Employees at Sengkaling Recreational Park has a scale range value of 888 which is included in the sufficient category. Career development is assessed based on four indicators namely individual career development, career development supported by the HR department, the role of the leader in career development and the role of feedback on career development.

The career development of individual employees in the company is still in the sufficient category. Evidenced by the lack of responsibility of employees to advance their careers. The lack of responsibility in the form of high employee absenteeism in 2017 reached 440 which resulted in a low performance appraisal that prevented the promotion.

Career development supported by the HR department in the company is still in the sufficient category. This means that the company has not fully supported the career needs of employees in the company. Evidenced by the lack of formal communication that includes all divisions so that an understanding of career development in the company can be accepted by all employees in each division.

The role of leaders in career development is included in the sufficient category. Leaders do not blend in with subordinates, lack of direct communication with subordinates makes the career development needs of employees less noticed. This is consistent with the results of interviews conducted with several employees who said that leaders pay more attention to job description control in each division than pay attention to the career development of employees.

The role of feedback on career development is also in the sufficient category. The feedback in question is work assessment information and rewards for employees who excel. 
The company provides work evaluation information to all employees once a year, the information is in the form of performance appraisal. However, the company does not provide feedback on this information in the form of consultation or guidance to employees in order to improve future performance.

\section{Work Environment of Malang Sengkaling Recreational Park Employees}

Based on the results of data analysis, it can be seen that the work environment of Employees at Sengkaling Recreational Park has a scale range value of 1,116 in the good category. The work environment is assessed based on 4 (four) indicators, namely light, temperature, air circulation and noise. All four indicators are included in the good category. The lighting in the company is good. Evidence by the optimization of lighting from sunlight and room lights to support the activities of employees who have a good impact on increasing productivity, work efficiency and reducing work errors.

Companies can regulate the temperature in the company properly. Air conditioning to remain normal in the workspace by placing the fan when the weather is hot or hot. Furthermore, air circulation within the company is also in the good category. The company places windows in every workspace to facilitate air exchange. This air exchange is important in order to create the availability of clean air that can be beneficial for health and can increase the work productivity of employees.

Furthermore, the last indicator is noise which is included in both categories. The location which is located on the edge of the road is actually the intensity of the high noise. However, the architect of the building that protrudes inside and repairs made previously make the workspace can reduce excessive noise from outside, especially the sound of motor vehicles. The low disturbing sound intensity can create conducive working conditions and increase the concentration of employees doing work activities.

\section{Effect of Career Development and Work Environment on Employee Job Satisfaction at Sengkaling Recreational Park}

Based on the results of the distribution of questionnaires and data analysis that has been done, it can be seen that career development and work environment simultaneously influence employee job satisfaction at Sengkaling Recreational Park. This condition shows that if the career development implemented by company management increases and the work environment applied increases, employee job satisfaction will increase.

The results of this study indicate that Employee job satisfaction at Sengkaling Recreational Park is determined by factors of career development and work environment and is significantly influenced by these factors. So it can be said that career development and work environment are factors that influence employee job satisfaction at Sengkaling Recreational Park. The results of this study reinforce the previous findings of research which states that career development and work environment simultaneously influence employee job satisfaction [7].

\section{Effect of Career Development on Job Satisfaction}

Based on the results of the distribution of questionnaires and data analysis that has been done, it can be seen that career development has a significant effect on employee job satisfaction at Sengkaling Recreational Park. Career development is the process of increasing individual work skills achieved in order to achieve the desired career [2]. Employees at the Sengkaling Recreation Park regulate promotions in the Director's Regulation, namely: a 
system of regular increases and promotion of ranks (awards for employee work performance) to occupy certain positions; work performance, work performance evaluation results are used as consideration for promotion and promotion; Increasing the ability and skills of employees who are considered capable of getting training and education inside and outside the company in accordance with company needs. Based on this fact, the career development process undertaken by the company is sufficient to affect the workforce of employees.

Career development implemented by the Sengkaling Recreational Park Company was stated to have a significant effect on employee job satisfaction. The results of this study reinforce the previous research which stated that career development has a significant effect on work aging [7], and career development has a significant effect on job satisfaction [10].

\section{Effect of Work Environment on Employee Satisfaction in Sengkaling Recreational Park}

Based on the results of the distribution of questionnaires and data analysis that has been done, it can be seen that the work environment has a significant effect on employee satisfaction at Sengkaling Recreational Park, so that the second hypothesis formulated is a convincing and meaningful hypothesis so that it can be accepted.

The findings in this study theoretically strengthen the description that the work environment is something that exists in the environment of workers that can affect employee job satisfaction in carrying out their work in order to obtain maximum work results [5]. The company creates a work environment with good lighting arrangement from the sun's rays and the placement of lights in each workspace. The company provides fans when the room starts to get hot. Placement of windows in each room also keeps the exchange of clean air from the outside to replace dirty air from inside the room. Based on the fact that there is in the company if it can be maintained even if the company is able to improve it can be interpreted that the work environment implemented by the company can increase employee job satisfaction.

The findings in this study conclude that the work environment created by the Sengkaling Park Recreational company significantly influences employee job satisfaction, empirically has strengthened the findings of previous research which stated that the work environment has a significant effect on job satisfaction [10] and the work environment has a significant effect on job satisfaction [8].

\section{Acknowledgement}

I am grateful to all of those with whom I have had the pleasure to work during this and other related projects. Nobody has been more important to me in the pursuit of this project than the members of my family. I would like to thank my parents, whose love and guidance are with me in whatever I pursue. They are the ultimate role models. Most importantly, I wish to thank my loving and supportive wife and my childrens who provide unending inspiration.

\section{References}

[1] J. E. Ormrod, Psikologi Pendidikan Membantu Siswa Tumbuh dan Berkembang. Edisi Keenam. Jakarta: Erlangga, 2008.

[2] V. Rivai, Manajemen Sumber Daya Manusia untuk Perusahaan : dari Teori ke Praktik. Jakarta, 2015.

[3] F. A. Naway and I. Haris, "The Effect of Career Development, Perception of Organizational Justice and Job Satisfaction on Teacher's Organizational Citizenship Behavior," Int. Rev. Manag. Mark., vol. 7, no. 2, pp. 17-21, 2017. 
[4] S. Shujaat, S. Sana, F. Aftab, and I. Ahmed, "Impact of Career Development on Employee Satisfaction in Private Banking Sector Karachie," J. Manag. Soc. Sci., vol. 9, no. 2, pp. 1-8, 2013.

[5] P. Afandi, Manajemen Sumber Daya Manusia: Teori, Konsep dan Indikator. Pekanbaru: Zanafa Publishing, 2018.

[6] R. Jain and S. Kaur, "Impact of Work Environment on Job Satisfaction,” Int. J. Sci. Res. Publ., vol. 4, no. 1, pp. 1-8, 2014.

[7] C. Astrika, Z. Zulfadil, and H. Haryetti, "Pengaruh Pengembangan Karir Dan Lingkungan Kerja Terhadap Kepuasan Kerja Karyawan PT. Johan Sentosa Bangkinang," J. Online Mhs. Fak. Ekon. Univ. Riau, vol. 4, no. 1, pp. 484-494, 2017.

[8] I. Prastowo, "Pengaruh Pengembangan Karir, Lingkungan Kerja dan Komitmen Organisasi terhadap Kepuasan Kerja Pegawai Hotel Sahid Jaya Solo dengan Keyakinan Diri (Self Effisasi) sebagai Variabel Pemoderisasi," J. Sainstech Politek. Indonusa Surakarta, vol. 1, no. 3, pp. 1-15, 2015.

[9] A. A. N. B. Dhermawan, I. G. A. Sudibya, and I. W. M. Utama, "Pengaruh Motivasi, Lingkungan Kerja, Kompetensi, dan Kompensasi terhadap Kepuasan Kerja dan Kinerja Pegawai di Lingkungan Kantor Dinas Pekerjaan Umum Provinsi Bali," Matrik J. Manajemen, Strateg. Bisnis dan Kewirausahaan, 2012.

[10] F. Mabruroh, I. Isharijadi, and A. L. Wijaya, "Pengaruh Lingkungan Kerja Dan Pengembangan Karir terhadap Kepuasan Kerja Karyawan Rumah Sakit Paru Dungus Madiun," FIPA Forum Ilm. Pendidik. Akunt., vol. 5, no. 1, 2017. 